\section{Tyramine Formation from Hail Tail Meat in the Course of Enzymatic Digestion*1}

Kunio Suetsuna ${ }^{* 2}$ and Kazuyuki Kunihiro*3 (Accepted June 27, 1986)

Tyramine which is produced from tyrosine by the action of L-tyrosine decarboxylase distributes widely in animals and plants., ${ }^{1,2)}$ Fruits and vegetables such as banana, plum, tomato, eggplant and potato contain tyramine at a concentration of 0.1 to $6.5 \mathrm{mg} / 100 \mathrm{~g} .^{3,4}$ Tyramine is used as medicine has the womb-contracting effect, the peripheral nervous system-contracting effect, the blood pressure-raising effect etc. and is also very important as a material for syntheses of certain medicines and for an ion sensor etc.. We found that tyramine was produced in fairly large quantity by the long time incubation of hair tail Trichurus lepturus meat with protease and can be easily isolated in a highly pure form. Five hundred grams of hair tail meat was homogenized with $5 l$ of deionized water. Ten grams of protease (Denazyme-AP, Nagase Biochemical $\mathrm{Co}$. Ltd.) was added to the homogenate whose $\mathrm{pH}$ has been adjusted to 7.0 with $1 \mathrm{~N}-\mathrm{NaOH}$, and the mixture was incubated for $20 \mathrm{~h}$ at $37^{\circ} \mathrm{C}$ with stirring. After beeing cooled the reaction mixture was filtered through a filter paper with suction, Fifty grams of activated carbon powder (Carboraffin, Takeda Chemical Industries Ltd.) was added to the filtrate. After beeing stirred the mixture was filtered again with suction to obtain a clear filtered. The filtrate was concentrated to $1 l$ under vacuum. To the concentrated filtrate $10 l$ of methanol was added. The mixture was left over night at a cool place and then resulting precipitates were removed by filtration with suction. The filtrate was concentrated to $500 \mathrm{ml}$ under vacuum and then pass through a cation exchange resin Dowex $50 \mathrm{~W}$ $\left[\mathrm{H}^{+}\right.$form $](\times 4,50-100$ mesh, column size $4.2 \times 15 \mathrm{~cm})$ column. After column was washed sufficiently with deionized water to remove adsorbed impurities, the desired constituent was eluated with $0.3 \mathrm{~N}-\mathrm{NH}_{4} \mathrm{OH}$ of 2 l. After beeing concentrated to $200 \mathrm{~m} /$ under vacuum the eluate was left over night at a cool place to obtain colorless acicular crystals. These crystals were collected by filtration of a glass filter G-4 with suction and then dried in the air. Yield: $4.8 \mathrm{~g}$ of purified tyramine. Anal. Found: C, 69.74; H, 8.30; N, 10.23\%. Calcd for $\mathrm{C}_{8} \mathrm{H}_{11} \mathrm{NO}: \mathrm{C}, 70.07 ; \mathrm{H}, 8.03 ; \mathrm{N}, 10.22 \%$. Infrared spectrum was in good agreement with that of authentic tyramine.

Tyramine formation during the incubation is presumed as follows: Tyrosine produced from hair tail meat proteins by protease action is converted into tyramine by L-tyrosine decarboxylase present as a contaminant in the protease preparation used. Further work is under way to elucidate the mechanism of tyramine formation.

\section{References}

1) K. Fukuhara, Y. Ishigami, R. Katsumura, T. Ito, Y. Matsuki, and T. Nambara: Nippon Shokuhineiseigaku Kaishi, 25, 384-387 (1982).

2) M. Nakagawa, A. Watanabe, and $\dot{T}$. Kariya: Tanpakushitsu Kakusan Kōso, 26, 1259-1265 (1981).

3) S. Udenfried, W. Lovenberg, and A. Sjoerdsma: Arch. Biochem. Biophys., 85, 487-489 (1959).

4) T. Matsumoto and T. Kaya: Nippon Nógeikagaku Kaishi, 56, 209-212 (1982).

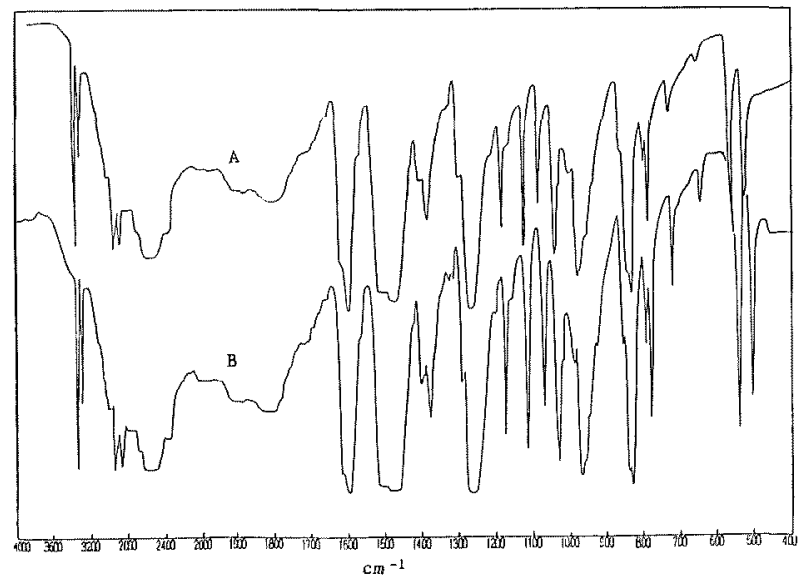

Fig. 1. Infrared spectrum of (B) Tyramine which was obtained from hair tail meat and (A) authentic tyramine.

*1 醭素分解過程に拈けるタチウオ肉からのチラミンの生成。

*2 Department of Food Science and Technology, Shimonoseki University of Fisheries, Yoshimi, Shimonoseki 759-65, Japan (本網邦男: 水産大学校製造学科).

*3 Research Laboratory, Hayashikane Sangyo \& Co., Yamato, Shimonoseki 750, Japan (国広和之: 林非 應菜(株) 開発部). 